\title{
Uji Efektivitas Sediaan Krim Kombinasi Ekstrak Daun Bakau Hitam (Rhizophora Mucronata) Dan Jeruk Purut (Citrus Hystrix) Terhadap Bakteri Staphylococcus Aureus
}

\author{
Dewi Kurnianingsih ${ }^{1,}$ Lulu Setiyabudi $^{2 *}$, Tatang Tajudin ${ }^{3}$ \\ ${ }^{1,2,3}$ Program Studi S1 Farmasi STIKES Al-Irsyad Al-Islamiyyah, Cilacap, Jawa Tengah, Indonesia \\ Email correspondence: "l.setivabudi@gmail.com
}

\begin{abstract}
ABSTRAK
Senyawa alkaloid, flavonoid dan tanin yang terdapat dalam daun bakau ( $R$. mucronata) dan minyak atsiri dari jeruk purut (C. hystrix) telah terbukti memiliki aktivitas sebagai antibakteri S. aureus. Penelitian ini merupakan pengembangan dari potensi aktivitas antibakteri S. aureus tersebut. Dimana ekstrak $R$. mucronata dan minyak atsiri $C$. hystrix dibuat menjadi sediaan krim tipe M/A. Formula krim dibuat dengan tiga variasi konsentrasi ekstrak yaitu 5\%, 10\%, dan 15\% dengan konsentrasi minyak atsiri C. hystrix masing-masingsebesar 5\%. Evaluasi sediaan krim dilakukan dengan stabilitas cycling test dan uji aktivitas antibakteri terhadap S. aureus. Data yang diperoleh dianalisis menggunakan One Way ANOVA dengan taraf kepercayaan 95\%. Hasil penelitian menunjukkan bahwa formulasi sediaan krim kombinasi $R$. mucronata dan minyak atsiri $C$. hystrix memiliki karakteristik fisik yang baik, akan tetapi mengalami penurunan kestabilan setelah dilakukan uji stabilitas cycling test. Penurunan kestabilan ini tidak berpengaruh secara signifikan pada karakteristik fisik sediaan krim. Hasil uji zona hambat bakteri pada konsentrasi 5\% memiliki efek antibakteri sedang, sedangkan pada konsentrasi 10\% dan 15\% memiliki efek antibakteri kuat. Hasil analisis statistik pada kosnsentrasi 10\% dan 15\% tidak terdapat perbedaan yang signifikan dalam menghambat bakteri S. aureus. Formulasi krim kombinasi R. mucronata dan minyak atsiri C. hystrix dengan konsentrasi ekstrak sebesar $10 \%$ adalah formula yang memiliki aktivitas antibakteri yang paling optimal.
\end{abstract}

Kata Kunci: C. hystrix, Krim, R. mucronata, S. aureus

\begin{abstract}
Alkaloid, flavonoid and tannin compounds found in the leaves of mangroves (R. mucronata) and essential oils from kaffir lime (C. hystrix) have been shown to have antibacterial activity as $S$. aureus. This research is a development of the potential antibacterial activity of $S$. aureus. Where $R$. mucronato extract and $C$ hystrix essential oil are made into type $M / A$ cream preparations. Cream formula is made with three variations of extract concentration which are 5\%,10\%, and 15\% with a concentration of essential oil of hystrix of 5\% each. Evaluation of cream preparations was carried out with a cycling test stability and antibacterial activity against $S$. aureus. The data obtained were analyzed using One Way ANOVA with a confidence level of $95 \%$. The results showed that the cream formulation combination of $R$. mucronata and C. hystrix essential oil had good physical characteristics, but experienced a decrease in stability after the cycling stability test. This decrease in stability does not significantly influence the physical characteristics of the cream preparation. The results of bacterial inhibition zone test at a concentration of 5\% have a moderate antibacterial effect, while at a concentration of $10 \%$ and $15 \%$ have a strong antibacterial effect. The results of statistical analysis at concentrations of $10 \%$ and $15 \%$ showed no significant difference in inhibiting the $S$. aureus bacteria. The combination of $R$. mucronata cream formulation and $C$. hystrix essential oil with extract concentration of $10 \%$ is the formula that has the most optimal antibacterial activity.
\end{abstract}

Keywords: Cream, C. hystrix. R. mucronata, S. Aureus 


\section{PENDAHULUAN}

Staphylococcus aureus merupakan bakteri gram positif yang diperkirakan 20-75\% ditemukan pada saluran pernafasan atas, muka, tangan, rambut dan vagina. Infeksi bakteri ini dapat menimbulkan penyakit yang khas, yaitu peradangan, nekrosis, infeksi folikel rambut, dan pembentukan abses[1]. Pengobatan yang biasa dilakukan untuk mengatasi infeksi bakteri adalah penggunaan antibiotik. Antibiotik merupakan senyawa obat yang dapat membunuh atau menghambat pertumbuhan bakteri.

Tanaman bakau hitam spesies Rhizophora mucronata merupakan tanaman yang memiliki kandungan metabolit sekunder (bioaktif) yang berpotensi sebagai antibakteri. Wilayah pesisir Kabupaten Cilacap merupakan salah satu habitat yang subur bagi tanaman $R$. mucronata. Berdasarkan penelitian[2], $R$. mucronata memiliki kandungan senyawa metabolit sekunder seperti alkaloid, tannin dan flavanoid yang memiliki aktivitas sebagai antibakteri.

Pemanfaatan minyak atsiri sebagai kombinasi dalam sediaan krim memiliki duaperan, yaitu dapat meningkatkan gradient konsentrasi serta meningkatkan aktivitas antibakteri. Salah satu minyak atsiri yang dapat dimanfaatkan adalah minyak atsiri jeruk purut (Citrus hystrix). Berdasarkan penelitian [3], bahwa minyak atsiri jeruk purut (Citrus hystrix) mempunyai aktivitas antibakteri terhadap $S$. aureus. Pada penelitian ini akan dibuat krim tipe M/A berbahan dasar kombinasi esktrak daun $R$. mucronata dan minyak atsiri $C$. hystrix.

\section{METODE PENELITIAN}

\subsection{Alat dan Bahan}

Alat yang digunakan pada penelitian ini adalah Neraca analitik Ohauss (PioneerTM), pisau, oven (memmert), blender (miyako), , cawan porselen, mortir, stampher, sudip, wadah krim, autoklaf (GEA model YX-18LM), inkubator (memmert), cawan petri, jarumose, bunsen, kompor listrik (maspion), vorteks (VM-300), tabung reaksi (Pyrex), mikro pipet (socorex), $\mathrm{pH}$ universal, objek glass, ekstensometer, anak timbangan 50 gram.

Bahan yang digunakan pada penelitian ini adalah Daun $R$. mucronata, minyak atsiri $C$. hystrix, paraffin liquidum, asam stearat, trietanolamin, adeps lanae, nipasol, nipagin, asam sulfat pekat, $\mathrm{NaCl}$ 0,9, Nutrient Agar (NA), Purified water, Magnesium (Mg) (Brataco), HCL Pekat (Brataco), $\mathrm{FeCl} 3$ (Brataco), NaCl, Aquadest (Brataco), alkohol 95\%, Nutrient Agar (NA), Pereaksi Sudan III, bakteri S. aureus.

\subsection{ProsedurPenelitian}

\section{Pengambilan Sampel}

a. Sampel Daun Bakau Hitam (R. Mucronata)

Sampel daun bakau hitam (R. mucronata) diambil Hutan Payau yang terletak di Desa Tritih Kulon, Kecamatan Cilacap Utara, Kabupaten Cilacap.

b. Sampel Minyak Atsiri Jeruk Purut (C. hystrix)

Minyak Atsiri Jeruk Purut (C. hystrix) yang digunakan dalam penelitian ini diperoleh dari PT. Darjeeling Sembrani Aroma.

2. Identifikasi Sampel Daun $R$. mucronata dan Minyak Atsiri $C$. hystrix

a. Identifikasi Daun $R$. mucronata

Identifikasi dilakukan dengan ciri-ciri morfologi dan makroskopis, selanjutnya membandingkan kesesuaian ciri-ciri morfologis dan makroskopis yang ada pada sampel daun bakau hitam ( $R$. mucronata) terhadap kepustakaan.

b. Identifikasi Minyak Atsiri $C$. hystrix

Identifikasi dan mutu bahan dilakukan dengan membandingkan data sampel pemeriksaan atau pengujian dengan menggunakan persyaratan standar, namun karena standar SNI. 


\section{Pembuatan Serbuk Daun $R$. mucronata}

Sampel daun $R$. mucronata sebanyak $5 \mathrm{~kg}$ dicuci bersih dengan air mengalir, kemudian dipotong kecil-kecil, dikeringkan dengan oven pada suhu $38-40^{\circ} \mathrm{C}$ selama 7 hari. Daun $R$. mucronata yang telah kering diblender menjadi serbuk. Serbuk kemudian diayak menggunakan ayakan no 40. Hasil penyerbukan disimpan dalam wadah kering dan tertutup rapat.

\section{Pembuatan Ekstrak Etanol Daun $R$. mucronata}

Proses maserasi menggunakan pelarut etanol $96 \%$ dengan perbandingan yaitu 1:5 (b/v). sebanyak 500 gram sampel direndam dengan etanol 96\% sebanyak 2,5L selama $3 \times 24$ jam. Hasil filtrat dipekatkan menggunakan waterbath dengan suhu $55^{\circ} \mathrm{C}$.

\section{Penetapan Kadar Air}

Pengujian kadar air dilakukan menggunakan oven. Proses yang dilakukan dengan cara cawan porselen disterilkan dalam Oven selama 1 jam dengan suhu $105^{\circ} \mathrm{C}$. kemudian didinginkan selama 15 menit dan ditimbang beratnya (A gram). Selanjutnya sampel ditimbang sebanyak 1 gram dan ditaruh dalam cawan porselen. Kemudian dikeringkan dalam oven pada suhu $105^{\circ} \mathrm{C}$ sampel konstan selama 1 jam, selanjutnya didinginkan dan ditimbang $(\mathrm{C}$ gram).

\section{Uji Bebas Etanol Ekstrak Daun $R$. mucronata}

Uji bebas etanol terhadap ekstrak etanol daun $R$. mucronata, dilakukan dengan menggunakan metode esterifikasi etanol, dengan cara diambil satu gram ekstrak daun $R$. mucronata lalu dimasukkan kedalam tabung reaksi ditambahkan $1 \mathrm{~mL}$ asam salisilat dan $1 \mathrm{~mL}$ asam sulfat pekat kemudian dihomogenkan dan dipanaskan diatas bunsen, atas tabung ditutup dengan kapas, ekstrak telah bebas etanol ditandai dengan tidak timbulnya bau ester.

\section{Skrining Fitokimia Ekstrak Daun R. Mucronata}

\section{a. Flavanoid}

Ekstrak ditimbang sebanyak 0,5 gram ditambahkan dengan etanol $70 \%$, kemudian ditambahkan 5-6 tetes $\mathrm{HCl}$ pekat. Hasil positif apabila membentuk warna merah [4].

\section{b. Alkaloid}

Sebanyak 0,5 gram serbuk dan ekstrak ditambah $1 \mathrm{ml} \mathrm{HCl} 2 \mathrm{~N}$ dan $9 \mathrm{ml}$ aquadest kemudian panaskan \pm 2 menit, filtrat ditambah pereaksi Dragendorff. Hasil positif ditunjukkan dengan terbentuk endapan, dan warna coklat kemerahan [5].

\section{c. Tanin}

Uji tanin dilakukan dengan cara mengambil larutan ekstrak sebanyak $1 \mathrm{~mL}$, kemudian ditetesi larutan $\mathrm{FeCl}_{3} 10 \%$ dan diamati terjadinya perubahan warna. Jika larutan berubah menjadi warna biru tua atau hijau kehitaman menunjukan[4]

\section{d. Minyak atsiri}

Pengujian minyak atsiri dilakukan dengan cara menimbang sebanyak 0,5 gram ekstrak dimasukkan dalam tabung reaksi, ditambah tetes pereaksi sudan III. Hasil menunjukkan reaksi positif jika larutan berwarna merah[6].

8. Formulasi Sediaan Krim Kombinasi R. mucronata dan C. Hystrix

Tabel 4. Rancangan Formula Sediaan Krim

\begin{tabular}{lccc}
\hline \multirow{2}{*}{ Bahan } & \multicolumn{2}{c}{ Konsentrasi Formula $(\mathbf{b} / \mathbf{v})$} & F3 \\
\cline { 2 - 4 } & $\mathbf{F 1}$ & $\mathbf{F 2}$ & 15 \\
Ektrak R. Mucrunata & 5 & 10 & 5 \\
Minyak atsiri C. Hystrix & 5 & 5 & 25 \\
Parafin Liquid & 25 & 25 & 14,5 \\
Asam stearat & 14,5 & 14,5 & 1,5 \\
trietanolamin & 1,5 & 1,5 & 3 \\
Adeps lanae & 3 & 3 & 0,18 \\
Nipagin & 0,18 & 0,18 & 0,05 \\
Nipasol & 0,05 & 0,05 & 100 \\
Aquadest ad & 100 & 100 & \\
\hline
\end{tabular}




\section{Karakteristik Fisik Krim}

\section{a. Uji Organoleptis}

Proses pengujian organoleptik dilakukan dengan pengamatan secara langsung terhadap parameter seperti warna, bau dan bentuk dari sediaan krim yang telah dibuat Uji Homogenitas

Masing-masing krim yang akan diuji dioleskan pada 3 buah gelas obyek untuk diambil homogenitasnya. Apabila tidak terdapat butiran-butiran kasar di atas ketiga gelas obyek tersebut maka krim yang diuji homogen. Pengujian homogen ini dilakukan sebanyak 3 kali.

b. Uji pH

Tujuan untuk mengetahui nilai $\mathrm{pH}$ sediaan krim yang terbentuk. Interpretasi hasil dari pengukuran $\mathrm{pH}$ yaitu didapatkan nilai $\mathrm{pH}$ yang dipersyaratkan untuk sediaan topikal dan sesuai untuk sediaan kulit harus berkisar antara $\mathrm{pH} 4,5$ dan $\mathrm{pH}$ 6,5 [7].

\section{c. Uji Viskositas}

Uji viskositas krim dilakukan dengan menggunakan alat Viskometer. Pengujian viskositas ini diulangi sebanyak tiga kali tiap formulanya. Pengujian Viskositas dilakukan tiap minggu selama satu bulan.

\section{d. Uji Daya Lekat}

Krim dengan berat 0,5 gram diletakkan pada gelas obyek dan ditekan dengan beban $1 \mathrm{~kg}$ selama 5 menit. Setelah itu gelas obyek dipasang pada alat tes yang diberi beban 80 gram dan kemudian dicatat waktu pelepasan krim dari gelas obyek. Pengujian dilakukan sebanyak 3 kali untuk setiap formulanya [8].

\section{e. Uji Daya Sebar}

Ditimbang 0,5 gram krim diletakkan di tengah alat (kaca bulat), kaca bulat bagian atas ditimbang terlebih dahulu dan diletakan diatas krim, biarkan selama 1 menit, diukur diameter krim yang menyebar (diambil panjang rata-rata diameter dari beberapa sisi), ditberi beban 50 gram, 100, gram, 150 gram, dan 200 gram. Cara diatas diulangi sebanyak 3 kali tiap fomulanya.

\section{f. Uji Tipe Krim}

Pengujian bertujuan untuk memastikan tipe emulsi yang dibuat sesuai dengan tipe emulsi yang diharapkan.

\section{g. Uji Stabilitas dengan Metode Cycling Test}

Tujuan perlakuan ini adalah untuk mengetahui kestabilan emulsi dalam sediaan krim. Pengujian cycling test untuk melihat adanya kristalisasi atau pemisahan setelah dilakukan perlakuan suhu yang berbeda dari suhu dingin $4^{\circ} \mathrm{C}$ dan suhu panas $40^{\circ} \mathrm{C}$.

\section{Uji Aktivitas Antibakteri}

Pada penelitian ini menggunakan 7 kelompok yaitu sediaan krim, kontrol negatif berupa sediaan krim tanpa zat aktif, kemudian kontrol positif berupa antibiotik gentamisin $1,2 \%$, serta kelompok pembanding yaitu dengan menggunakan aquadest. Metode uji antibakteri yang digunakan pada penilitian ini adalah difusi sumuran.

\section{Teknik Pengumpulan Data}

Teknik pengumpulan data dari penelitian ini dilakukan dengan mencatat pelaksanaan penelitian dengan logbook dan ceklist.

\section{Analisa Data Statistika}

Analisa Data Statistika menggunakan metode analisis One Way Anova dengan derajat kepercayaan $95 \%$. 


\section{HASIL DAN PEMBAHASAN}

\section{A. Pengambilan Sampel}

\section{Pengambilan Sampel Daun $R$. mucronata}

Kriteria daun R. mucronata yang digunakan dalam penelitian ini adalah bagian pucuk daun yang masih muda, utuh, dan masih segar.

\section{Sampel Minyak Atsiri C. Hystrix}

Sampel minyak atsiri jeruk purut (C. hystrix) yang digunakan dalam penelitian ini merupakan hasil minyak atsiri yang berasal PT. Darjeeling Sembrani Arom.

\section{B. Identifikasi Sampel Daun $R$. mucronata dan Minyak Atsiri $C$. hystrix}

\section{Identifikasi Daun $R$. mucronata}

Karakteristik dari daun $R$. mucronata sesuai dengan morfologi tanaman yang digunakan dalam penelitian ini, sehingga dapat disimpulkan bahwa tanaman $R$. mucronata yang digunakan dalam penelitian ini adalah benar $R$. mucronata.

\section{Identifikasi Sampel Minyak Atsiri $C$. hystrix}

Minyak atsiri jeruk purut $C$. hystrix yang diperoleh dari PT. Darjeeling Sembrani Aroma, berdasarkan data dapat disimpulkan memenuhi persyaratan standar mutu minyak atsiri jeruk purut $C$. hystrix yang ditetapkan.

\section{Pembuatan Serbuk Daun $R$. mucronata}

Pembuatan serbuk daun $R$. mucronata segar sebanyak $5 \mathrm{~kg}$ setelah dikeringkan bobot nya susut menjadi bobot kering $1,3 \mathrm{~kg}$. Daun kering yang telah disortasi kemudian dihaluskan. Berdasarkan perhitungan rendemen pengeringan daun simplisia kering $R$. mucronata, sehingga diperoleh nilai rendemen bobot kering daun $R$. mucronata sebesar $26 \%$. Hasil pengamatan organoleptik daun kering $R$. mucronata ditunjukan pada tabel 6 .

Tabel 6. Hasil Organoleptis Simplisia Kering R. mucronata

\begin{tabular}{ccc}
\hline No & Evaluasi & Hasil \\
\hline 1 & Bau & Khas \\
2 & Warna & Coklat \\
3 & Rasa & Pahit \\
4 & Bentuk & Serbuk \\
\hline
\end{tabular}

\section{Pembuatan Ekstrak Etanol $R$. mucronata}

Ekstraksi dilakukan menggunakan metode maserasi. Hasil ekstraksi maserasi dari sampel serbuk daun $R$. mucronata sebanyak 500gram menghasilkan ekstrak etanol pekat daun $R$. mucronata yang berwarna hijau kehitaman sebesar 36,5 gram, dengan nilai rendemen sebesar 7,3\%.

\section{E. Penetapan Kadar Air}

Penetapan kadar air bertujuan untuk mengetahui kualitas bahan yang digunakan atas kandungan air yang terkandung dalam suatu sampel. Hal ini dikarenakan air merupakan media tumbuh dan berkembangnya jamur. Berdasarkan nilai batas persyaratan untuk kadar air yang terkandung dalam baku simplisia kering tidak boleh melebihi batas $>10 \%$. Kadar air yang lebih dari 10\% dapat meningkatkan risiko tumbuhnya jamur[9]. Berdasarkan hasil perhitungan kadar air terhadap simplisia daun $R$. mucronata didapatkan nilai sebesar $7 \%$. Sehingga dapat diketahui bahwa ektrak etanol $R$. mucronata cukup aman dari kontaminasi jamur.

F. Uji Bebas Etanol Ekstrak R. mucronata

Berdasarkan hasil penelitian, didapatkan tidak timbulnya bau ester dari hasil reaksi esterifikasi yang dilakukan. Menunjukkan bahwa tidak terbentuknya senyawa aspirin

\section{G. Skrining Fitokimia}

1. Ekstraksi Daun Mangrove $R$. mucronata

Identifikasi kandungan senyawa aktif dalam ekstrak yang dilakukan dengan menggunakan uji tabung (melihat warna dan endapan). Hasil uji skrining fitokimia ekstrak daun mangrove $R$. mucronata seperti disajikan tabel berikut. 
Tabel 7. Hasil skrining Fitokimia Ekstrak Etanol $R$. mucronata

\begin{tabular}{ccccc}
\hline No & Pemeriksaan & Pereaksi & Hasil & Keterangan \\
\hline 1. & Alkaloid & Dragendorff & + & Jingga \\
2. & Flavonoid & $\mathrm{Mg}+\mathrm{HCl}$ & + & Coklat Kemerahan \\
3. & Tanin & $\mathrm{FeCl}_{3}$ & + & hijau kehitaman \\
\hline
\end{tabular}

\section{Minyak Atsiri Jeruk Purut (C. hystrix)}

Berdasarkan hasil uji identifikasi minyak atsiri dari sampel minyak atsiri $C$. hystrix didapatkan bahwa secara organoleptis dan reaksi identifikasi menggunakan pereaksi Sudan III menunjukkan bahwa pada pengujian minyak atsiri $C$. hystrix yang digunakan dalam penelitian ini adalah benar minyak atsiri dengan terbentuknya warna merah merata.

\section{H. Formulasi Sediaan Krim}

Tabel 8. Rancangan Formula Sediaan Krim [14]

\begin{tabular}{lccc}
\hline \multirow{2}{*}{ Bahan } & \multicolumn{3}{c}{ Konsentrasi Formula (b/v) } \\
\cline { 2 - 4 } & Formula 1 (\%) & Formula 2 (\%) & Formula 3 (\%) \\
\hline E. R. Mucrunata & 5 & 10 & 15 \\
Minyak atsiri C. hystrix & 5 & 5 & 5 \\
Parafin Liquid & 25 & 25 & 25 \\
m stearat & 14,5 & 14,5 & 14,5 \\
Trietanolamin & 1,5 & 1,5 & 1,5 \\
Adeps lanae & 3 & 3 & 3 \\
Nipagin & 0,18 & 0,18 & 0,18 \\
Nipasol & 0,05 & 0,05 & 0,05 \\
Aquadest ad & 100 & 100 & 100 \\
\hline
\end{tabular}

\section{Evaluasi Fisik Krim Sebelum dan Setelah Penyimpanan Cycling Test}

\section{Pengamatan Organoleptik}

Hasil uji pengamatan secara organoleptis menunjukkan bahwa krim ekstrak $R$. mucronata dengan konsentrasi 5\%, 10\%, 15\% dan minyak atsiri C. hystrix 5\%, menghasilkan perbedaan warna pada krim yang terbentuk. Perbedaan warna disebabkan karena perbedaan konsentrasi ekstrak yang digunakan, semakin tinggi konsentrasi ekstrak yang ditambahkan, menghasilkan gradient warna krim yang lebih gelap. Berdasarkan uji stabilitas diketahui bahwa warna, bau dan konsistensi bentuk krim tidak mengalami perubahan setelah diuji stabilitas cycling test. Sehingga dapat disimpulkan, sediaan yang dihasilkan memiliki warna yang menarik, bau yang khas, dan konsistensi bentuk yang baik karena dalam ketiga formula sediaan krim tersebut tetap stabil. Hal ini berarti tidak adanya perubahan fisik selama pengujian stabilitas cycling test sehingga uji stabilitas krim sudah sesuai dengan pustaka[10].

\section{Uji Homogenitas Krim}

Hasil pengamatan uji homogenitas sebelum dan sesudah proses pengujian cycling test. Hasilpengujian homogenitas menunjukkan bahwa krim ekstrak $R$. mucronata dan minyak atsiri $C$. hystrix sebelum dan sesudah proses pengujian stabilitas cycling test menunjukkan susunan yang homogen, ditandai dengan warna sediaan krim merata tidak terdapat partikel-partikel yang menggumpal. Uji homogenitas sediaan krim ekstrak $R$. mucronata dan minyak atsiri $C$. hystrix menunjukkan bahwa krim tetap homogen selama waktu penyimpanan dan tidak ada terjadinya pemisahan dari sediaan krim.

\section{Penentuan Nilai pH Sediaan Krim}

Berdasarkan penelitian, secara keseluruhan rentang $\mathrm{pH}$ yang diperoleh pada penyimpanan suhu $4^{\circ} \mathrm{C}$ dan $\mathrm{Suhu} 40^{\circ} \mathrm{C}$ dingin dan suhu suhu dingin, diperoleh nilai pH 6 yang masih termasuk dalam rentang $\mathrm{pH}$ normal untuk sediaan krim menurut SNI.

\section{Uji Viskositas}

Berdasarkan hasil pengujian dari krim stabilitas cycling test, sediaan krim mengalami penurunan viskositas, hal ini dapat disebabkan karena pengaruh suhu pada 
pengujian cycling test membuat viskositas dari krim menurun. hal ini terjadi dikarenakan perubahan suhu menyebabkan degradasi oksidatif pada rantai polimer surfaktan sehingga menyebabkan penurunan viskositas[11]. Berdasarkan hasil sediaan krim yang dibuat menunjukkan sediaan krim masih memenuhi syarat sediaan emulsi SNI 16-4399-1996 yaitu berada dalam kisaran nilai antara 2.000-50.000 cPs.

\section{Uji daya Lekat}

Pada pengamatan daya lekat krim dilakukan secara uji stabilitas cycling test, setelah dilakukan pengujian cycling test menunjukkan terjadinya penurunan nilai daya lekat terhadap masing-masing formula. Hal ini dapat disebabkan karena pada sediaan krim telah terjadi penurunan nilai viskositas. Nilai viskositas berhubungan linier dengan nilai daya lekat. Berdasarkan hasil penelitian, dapat disimpulkan hanya pada formula 3 yang memiliki nilai daya lekat sebesar 5,03 yang memenuhi persyaratan rentang nilai SNI yaitu 5-7 detik.

\section{Uji Daya Sebar}

Berdasarkan hasil penelitian uji daya sebar krim ekstrak $R$. mucronata dan minyak atsiri $C$. hystrix mengalami penurunan nilai daya sebar berbanding terbalik dengan peningkatan konsentrasi ekstrak. Diameter penyebaran konsentrasi $15 \%$ lebih kecil dibandingkan konsentrasi 5\% dan 10\%. Berdasarkan hasil penelitian, dapat disimpulkan hanya pada formula 1 dan 2 memiliki nilai daya sebar yang memenuhi persyaratan rentang nilai SNI.

\section{Uji Tipe Krim}

Hasil dari pengamatan tipe krim pada semua formula sediaan yaitu bersifat minyak dalam air (M/A). Hal ini dibuktikan dengan medium dispersi yang berwarna biru, sedangkan fase dispersi yang berupa droplet tidak berwarna biru.

\section{J. Aktivitas Antibakteri Sediaan Krim}

Aktivitas hambat bakteri sediaan krim ekstrak $R$. mucronata dan minyak atsiri $C$. hystrix pada konsentrasi 5\%; 10\%; dan 15\% memiliki rata-rata diameter zona hambat yang termasuk dalam kategori sedang dan kuat. F1 menunjukan aktivitas antibakteri sebesar 7,53 $\mathrm{mm}$. Pada F2 menunjukan luas zona hambat $11,76 \mathrm{~mm}$ dan pada F3 menunjukan luas zona hambat 12,26 $\mathrm{mm}$ tergolong kuat. Sehingga dapat disimpulkan bahwa peningkatan konsentrasi ekstrak berhubungan dengan peningkatan luas zona hambat yang diperoleh.

Berdasarkan data hasil analisis statistik, diketahui bahwa pada F1 dengan konsentrasi $5 \%$ menunjukkan adanya perbedaan yang signifikan terhadap formula krim F2, F3, dan kontrol (+). Sehingga dapat dikatakan bahwa F1 menunjukkan efek yang berbeda dalam menghambat pertumbuhan bakteri S. aureus. Sedangkan, hasil pada F2 dan F3 tidak memberikan adanya perbedaan yang signifikan.

\section{KESIMPULAN}

Ekstrak etanol daun $R$. mucronata dan minyak atsiri $C$. hystrix dapat diformulasikan menjadi krim kombinasi tipe M/A. Ketiga formula krim kombinasi dari ekstrak $R$. mucronata dengan variasi konsentrasi 5\%,10\%, dan $15 \%$, serta minyak atsiri $C$. hystrix 5\%, mempunyai aktivitas antibakteri secara in vitro terhadap bakteri $S$. aureus, dan aktivitas antibakteri paling optimal ditunjukan pada konsentrasi $10 \%$. Ketiga formula krim setelah dilakukan pengujian stabilitas cycling test mengalami penurunan stabilitas tapi tidak secara signifikan, sehingga dapat disimpulkan bahwa ketiga sediaan krim memiliki stabilitas baik 


\section{DAFTAR PUSTAKA}

[1] A. Chairani and E. Harfiani, "The Effectiveness of Jatropha multifida L. sap as Antiseptic Against Staphylococcus aureus, Escherichia coli and Candida sp. growth In Vitro," JK Unila, vol. 2, no. 2, pp. 84-92, 2018, doi: https://doi.org/10.23960/jk\%20unila.v2i2.1942.

[2] N. Paju, P. V. . Yamlean, and N. Kojong, "Uji efektivitas salep ekstrak daun binahong (Anredera cordifolia ( Ten .) Steenis) pada kelinci ( Oryctolagus cuniculus) yang terinfeksi bakteri Staphylococcus aureus," PHARMACON J. Ilm. Farm. - UNSRAT, vol. 2, no. 01, pp. 51-62, 2013, doi: https://doi.org/10.35799/pha.2.2013.885.

[3] R. Yuliani, P. Indrayudha, and S. S. Rahmi, "AKTIVITAS ANTIBAKTERI MINYAK ATSIRI DAUN JERUK PURUT (Citrus hystrix) TERHADAP Staphylococcus aureus DAN Escherichia coli," Pharmacon J. Farm. Indones., vol. 12, no. 2, pp. 50-54, 2011, doi: 10.23917/pharmacon.v12i2.31.

[4] E. S. Kaseng, N. Muhlishah, and S. Irawan, "Uji Daya Hambat Terhadap Pertumbuhan Bakteri Uji Staphylococcus aureus dan Escherichia coli Ekstrak Etanol Daun Mangrove Rhizophora mucronata dan Efek Antidiabetiknya Pada Mencit yang Diinduksi Aloksan," J. Bionature, vol. 17, no. 1, pp. 1-6, 2016, doi: https://doi.org/10.35580/bionature.v17i1.2587.

[5] S. E. Priani, W. K. Dewi, and A. Gadri, "Formulasi Sediaan Mikroemulsi Gel Anti Jerawat Mengandung Kombinasi Minyak Jinten Hitam (Nigella sativa L.) dan Minyak Zaitun (Olea europaea L.)," Kartika J. Ilm. Farm., vol. 6, no. 2, p. 57, 2019, doi: 10.26874/kjif.v6i2.143.

[6] M. Aria, S. T. J. Fendri, and H. Muqaddar, "UJI EFEK STIMULAN SISTEM SARAF PUSAT EKSTRAK ETANOL DAUNPEGAGAN (Centella asiatica(L.) Urban) TERHADAP MENCIT PUTIH BETINA," Sci. J. Farm. dan Kesehat., vol. 7, no. 1, p. 35, 2017, doi: 10.36434/scientia.v7i1.103.

[7] R. I. Tranggono and F. Latifah, "Buku Pegangan Ilmu Pengetahuan Kosmetik," Buku Pegangan Ilmu Pengetahuan Kosmetik. 2007.

[8] S. H. Yuliani, Y. Rahmadani, and E. P. Istyastono, "Irritation Test of Wound Healing Gel of Ethanolic Extract of Binahong Leaf Using Slug Irritation Test," J. Ilmu Kefarmasian Indones., vol. 14, no. 2, pp. 135-140, 2016, [Online]. Available: http://jurnalfarmasi.or.id/index.php/jifi/article/view/22.

[9] D. R. Ditjen POM, "Parameter standar umum ekstrak tumbuhan obat, Jakarta: Departement Kesehatan Republik Indonesia," Ed. IV, 2000, doi: 615.32.

[10] R. Voight, "Buku Pengantar Teknologi Farmasi," Yogyakarta, Univ. Gadjah Mada Press., 1994.

[11] I. Nandi, M. Bari, and H. Joshi, "Study of isopropyl myristate microemulsion systems containing cyclodextrins to improve the solubility of 2 model hydrophobic drugs," AAPS PharmSciTech, 2003, doi: 10.1208/pt040110. 